\title{
ASSOCIATION BETWEEN TRANSFORMING GROWTH FACTOR- $\beta 1$ AND INTERLEUKIN-4 AND CHILDHOOD ASTHMA IN ZAGAZIG UNIVERSITY HOSPITALS
}

\author{
Mohamed Sanad Naguib: Professor of Pediatrics, faculty of medicine, Zagazig University, Egypt. \\ Mohamed Mohamed Abd-Elsalam: Ass. Prof. of Pediatrics, faculty of medicine, Zagazig University, Egypt. \\ Amal Saeed Abd El-Azeem: Ass. Prof. of Medical Biochemistry, faculty of medicine, Zagazig University, \\ Egypt. \\ Yousif Mohamed Yousif: Ass. lecturer of Pediatrics, faculty of medicine, Zagazig University, Egypt.
}

\begin{tabular}{ll} 
Corresponding author & \multicolumn{1}{c}{ ABSTRACT } \\
& Background: Interleukin (IL) 4 and transforming growth factor $\beta 1$ (TGF- $\beta 1$ ) \\
Yousif Mohamed Yousif & astwo key cytokines involved in a Th2-type inflammation characteristic of \\
ael.: 01001246898 & trigger broncho-constriction, mucus over-production, and remodeling of \\
E Mail: & airways which augment inflammatory reactions in asthma. \\
Obamsesi4all@yahoo.com & 4 and TGF- $\beta 1$ with asthma development and further effect on its control level \\
& in Egyptian children. \\
& Subjects and methods: In this case-control study, two groups of children aged \\
& $5-15$ years were recruited: first diagnosed as cases of asthma (clinically and \\
& spirometry-based); the second group of non-asthmatic children was enrolled as \\
& controls. Serum levels of total IgE, IL 4 and TGF- $\beta 1$ were measured for all \\
& children. Cases were classified as controlled, partly controlled and uncontrolled \\
& (according to GINA 2008) \\
& Results: From December 2013 to Mai 2015,156 cases and 156 controls were \\
& recruited. \\
& Serum level of serum total IgE, TGF- $\beta 1$ and IL4 were significantly higher in \\
asthmatic in comparison to non-asthmatic children. A positive correlation \\
between serum levels of both total IgE and IL-4 and TGF- $\beta 1$ were noted. A \\
higher serum level of total IgE, TGF- $\beta 1$ and IL4 were noticed in children with \\
poor asthma control. \\
Conclusion: The data suggests that increased serum levels both TGF- $\beta 1$ and \\
IL4 in asthmatic children are associated with poor asthma control. \\
Keywords: Asthma, IL4, TGF- $\beta 1$
\end{tabular}

\section{INTRODUCTION}

A sthma is a chronic inflammatory disease of the lung characterized by airways remodeling, in which many cells and cytokines play an underlying important role. These cytokines produced by $\mathrm{T}$ lymphocytes contribute to the different pathogenic features of asthma ${ }^{[1]}$

The main underlying immunologic basis of asthma is Thl/Th2 imbalance in T helper cells sub-types. The decrease in Th1 cytokine production and increase in $\mathrm{Th} 2$ cytokine production result in increased IgE synthesis, which induces the degranulation of both mast cells and eosinophils with resultant airways hyper-reactivity and inflammatory response $^{[2]}$

IL-4 is a cytokine which considered the hallmark of Th2 cells. It is responsible for many underlying physiological disturbances associated with asthma. IL-4 is responsible mainly for switching B lymphocyte from IgM to $\operatorname{IgE}{ }^{[3]}$

TGF- $\beta 1$ is a multifunctional cytokine that influences asthma and is responsible mainly for airway remodeling. It plays an important role in growth, transformation, tissue repair and fibrosis of airways and thus modulating its inflammatory immune response ${ }^{[4]}$

Asthma symptom control and treatment response is variable in-between patients. Different asthmatics have various asthma severity levels and disease progress depends on multiple factors including their underlying cytokine assay ${ }^{[5]}$

The need for better asthma management makes us improve our knowledge about asthma underlying pathogenic mechanisms and the role of different factors which 
contribute to airway inflammation or influence clinical outcome ${ }^{[6]}$

On reviewing other previous studies, none have examined the effects of both cytokines on asthma in the Egyptian population. This is important as populations may be affected by ethnic or racial specific modifiers, which has an influence on genetic effects

Studies on the association of serum levels of IL4 and TGF- $\beta 1$ with the risk of asthma and their effect on the asthma control level are controversial; therefore we attempted to verify the relationship between serum levels of IL 4 and TGF- $\beta 1$ and asthma in Egyptian children.

\section{MATERIALS AND METHODS}

\section{Study design and setting}

Our present study group consisted of 156 cases and 156 controls, who were recruited from the outpatient pediatric pulmonology clinic and inpatient ward, Department of Pediatrics, Zagazig University in Egypt. All the patients were diagnosed according to the Expert Panel Report (EPR) ${ }^{[7]}$

The study design was approved by the Zagazig University ethical committee. A written informed consent was obtained from the caregiver of each participant before the start of the study.

\section{Inclusion criteria: \\ SUBJECTS AND SAMPLES}

Asthmatic children, 5-15 years of age with clinically and spirometric-based diagnosis of asthma were included randomly at first in our study. Another nonasthmatic unrelated nonallergic age and sex matched control group with same ethnicity were selected randomly after completion of cases recruitment. Those patients were 15 years or younger which is the upper limit of care either in our pediatric pulmonology outpatient clinic or inward admission.

\section{Exclusion criteria:}

- Children younger than 5 years of age whose spirometric evaluation can't be assessed.

- Patients with severe co-morbidities e.g cancer, autoimmune diseases..etc

- Patients on systemic steroids or oral antiinflammatory drugs which may induce changes in cytokine level
The cases were classified into three groups on the basis of asthma control level according to GINA guidelines ${ }^{[8]}$

Sampling

A total of $5 \mathrm{ml}$ venous blood was taken from each subject for further serological study.

\section{Data measurement}

Demographic, environmental and clinical and physical examination findings were recorded for all cases and controls included in the present study.

Measurement of total IgE, IL4, and TGF$\boldsymbol{\beta 1}$

The concentrations of total $\mathrm{IgE}(\mathrm{IU} / \mathrm{ml})$, IL $4(\mathrm{pg} / \mathrm{ml})$ and TGF- $\beta 1(\mathrm{pg} / \mathrm{ml})$ in serum were determined using An ELISA kits according to the manufacturer's instructions.

\section{Spirometry}

Pulmonary function tests were performed for all children using a fully computerized Spirometer (Jaeger MasterScreen $^{\mathrm{TM}}$ IOS, version 5.2 manufactured by VIASYS Healthcare GmbH, Hoechberg, Germany)

Pulmonary functions were assessed using forced expiratory volume in 1 second (FEV1), forced vital capacity (FVC) and the FEV1/FVC ratio, measured and expressed as a percentage of predicted values with a ratio higher than 0.9 being normal.

\section{STATISTICAL ANALYSIS}

SPSS version 20.0 was used for statistical analyses. According to the type of data, the following tests were used to test differences for significance:

- Differences between qualitative variables and percentages in groups were compared by Chisquare test.

- Differences between parametric quantitative independent groups by t-test, in nonparametric by Man Whitney and multiple by ANOVA

- Non parametric by Kruskal Wallace.

- Correlation by Pearson correlation

The significance level for all statistical tests was set at $P$ value $<0.05$. 


\section{RESULTS}

This study was conducted from December 2013-Mai 2015. 312 patients were included (156 cases and 156 controls) and their demographical characteristics are represented in Table (1)

Table (1): Demographic characteristics of studied groups

\begin{tabular}{|c|c|c|c|c|c|c|}
\hline Age & $\mathbf{N}$ & Mean & SD & $\begin{array}{l}\text { Std. error } \\
\text { Mean }\end{array}$ & $\mathbf{t}$ & $P$ \\
\hline Cases & 156 & 8.23 & 2.8 & 0.224 & \multirow{2}{*}{-1.008} & \multirow{2}{*}{0.31} \\
\hline Controls & 156 & 8.52 & 2.33 & 0.186 & & \\
\hline Sex & Count & Cases & Controls & Total & $\mathbf{X}^{2}$ & $P$ \\
\hline \multirow{2}{*}{ Males } & $\mathbf{N}$ & 94 & 96 & 190 & \multirow{6}{*}{0.054} & \multirow{6}{*}{0.81} \\
\hline & $\%$ & $60.3 \%$ & $61.5 \%$ & $60.9 \%$ & & \\
\hline \multirow{2}{*}{ Females } & $\mathbf{N}$ & 62 & 60 & 122 & & \\
\hline & $\%$ & $39.7 \%$ & $38.5 \%$ & $39.1 \%$ & & \\
\hline \multirow{2}{*}{ Total } & $\mathbf{N}$ & 156 & 156 & 312 & & \\
\hline & $\%$ & $100 \%$ & $100 \%$ & $100 \%$ & & \\
\hline
\end{tabular}

The above table revealed that the mean age of both cases and control groups was 8.2 and 8.5 years respectively with no statistically significant difference between both groups suggesting that both groups were matched regarding their age.

The table revealed also that, the cases were divided into (94) males and (62) females and the control group included (96) males and (60) females with no statistically significant difference between both groups suggesting that both groups were matched regarding their sex.

Table (2): Comparison between Serum levels of total IgE, IL-4 and TGF-ß1 in different studied groups

\begin{tabular}{|c|c|c|c|c|c|c|}
\hline & Group & $\mathbf{N}$ & Mean & SD & $\begin{array}{c}\text { Man } \\
\text { Whitney } \mathrm{Z} \\
\end{array}$ & $\boldsymbol{P}$ \\
\hline \multirow{2}{*}{$\operatorname{IgE}$} & Cases & 156 & 85.46 & 87.57 & \multirow{2}{*}{7.28} & \multirow{2}{*}{0.001} \\
\hline & Control & 156 & 30.81 & 33.23 & & \\
\hline \multirow{2}{*}{$\begin{array}{c}\text { IL-4 } \\
(\mathrm{pg} / \mathrm{ml})\end{array}$} & Cases & 156 & 70.83 & 56.03 & \multirow[b]{2}{*}{10.98} & \multirow[b]{2}{*}{0.001} \\
\hline & $\begin{array}{c}\text { Control } \\
\mathrm{s} \\
\end{array}$ & 156 & 15.33 & 14.27 & & \\
\hline \multirow[b]{2}{*}{ TGF-ß1 (pg/ml) } & Cases & 156 & 233.68 & 107.27 & \multirow{2}{*}{13.3} & \multirow[b]{2}{*}{0.001} \\
\hline & $\begin{array}{c}\text { Control } \\
\mathrm{s}\end{array}$ & 156 & 97.76 & 28.14 & & \\
\hline
\end{tabular}

The above table revealed that the mean serum level of serum total IgE, IL-4 and TGF$\beta 1$ were significantly higher in asthmatic children in comparison to their age and sex matched non-asthmatics 
Table (3): Correlation between the age of patients, total IgE, IL-4 and TGF-ß1

\begin{tabular}{cccccc} 
& Correlation & Age & IgE & IL-4 & TGF- $\beta 1$ \\
\hline \multirow{2}{*}{ Age } & $\mathrm{R}$ & 1 & -0.047 & -0.062 & -0.073 \\
\cline { 2 - 6 } & $\mathrm{P}$ & & 0.412 & 0.278 & 0.202 \\
\hline \multirow{2}{*}{ IgE } & $\mathrm{R}$ & -0.047 & 1 & $0.754^{* *}$ & $0.56^{* *}$ \\
\cline { 2 - 6 } & $\mathrm{P}$ & 0.412 & & 0.001 & 0.001 \\
\hline \multirow{2}{*}{ IL-4 } & $\mathrm{R}$ & -0.062 & $0.754^{* *}$ & 1 & $0.711^{* *}$ \\
\hline \multirow{2}{*}{ TGF- $\beta 1$} & $\mathrm{P}$ & 0.278 & 0.001 & & 0.001 \\
\cline { 2 - 6 } & $\mathrm{R}$ & -0.073 & $0.56^{* *}$ & $0.711^{* *}$ & 1 \\
\hline
\end{tabular}

The above table revealed no correlation between age of the patients and their serum levels of total IgE, IL-4 and TGF- $\beta 1$ while statistically, significant positive correlation between serum levels of both total IgE and IL-4 and TGF- $\beta 1$ were noted.

Table (4): Effect of serum levels of total IgE, IL-4 and TGF- $\beta 1$ in patients on asthma control level

\begin{tabular}{|c|c|c|c|c|c|c|c|c|}
\hline & $\begin{array}{c}\text { Asthma control } \\
\text { level }\end{array}$ & $\mathbf{N}$ & Mean & SD & Min. & Max. & $\begin{array}{l}\text { Kruskal } \\
\text { Wallace }\end{array}$ & $\mathbf{P}$ \\
\hline \multirow{3}{*}{$\begin{array}{l}\text { IgE } \\
\text { (IU/I) }\end{array}$} & Controlled & 67 & 28.04 & 26.48 & 8 & 114 & \multirow{3}{*}{116.2} & \multirow{3}{*}{0.001} \\
\hline & Partly controlled & 42 & 64.28 & 52.44 & 10 & 180 & & \\
\hline & Uncontrolled & 47 & 186.23 & 82.46 & 18 & 360 & & \\
\hline \multirow{3}{*}{$\begin{array}{c}\text { IL-4 } \\
(\mathrm{pg} / \mathrm{ml})\end{array}$} & Controlled & 67 & 20.32 & 20.53 & 8 & 126 & \multirow{3}{*}{257} & \multirow{3}{*}{0.001} \\
\hline & Partly controlled & 42 & 78.04 & 34.32 & 14 & 142 & & \\
\hline & Uncontrolled & 47 & 136.38 & 27.77 & 80 & 233 & & \\
\hline \multirow{3}{*}{$\begin{array}{l}\text { TGF- } \beta 1 \\
(\mathrm{pg} / \mathrm{ml})\end{array}$} & Controlled & 67 & 170.53 & 50.88 & 110 & 309 & \multirow{3}{*}{81.77} & \multirow{3}{*}{0.001} \\
\hline & Partly controlled & 42 & 205.73 & 70.27 & 85 & 341 & & \\
\hline & Uncontrolled & 47 & 348.68 & 103.07 & 100 & 552 & & \\
\hline
\end{tabular}

The above table revealed a statistically significant effect of the serum level of total IgE, IL-4, and TGF- $\beta 1$ on the asthma control among asthmatic children with higher serum values were associated with poor asthma control and significantly lower values were noticed in asthmatic children with good control level

\section{DISCUSSION}

Asthma is the most common chronic airway inflammatory disease of children. It is characterized by bronchial hyperresponsiveness which leads to remodeling and lastly intractable airflow obstruction ${ }^{[9]}$

There is an underlying complex pathogenetic process which leads to the development of airway inflammation, bronchial hyper-reactivity, recurrent episodes of wheezing and dyspnea. ${ }^{[10]}$
Asthmatics are characterized by a Th2type inflammation in their airways, which leads to increased number of inflammatory cells that produce cytokines which trigger broncho-constriction, mucus secretion, and permanent airway remodeling ${ }^{[9]}$

This present case-control study was conducted to assess the association of IL 4 and TGF- $\beta 1$ with asthma and their effect on asthma control in the Egyptian population.

We found both were elevated in asthmatics above nonasthmatic children. Moreover, they were associated with higher total IgE level and poor asthma control.

Our data revealed that both groups; asthmatics (cases) and non-asthmatics (controls) are closely matched regarding their age and gender where no statistically significant difference between both groups 
was found ( $\boldsymbol{p}$ - value of 0.31 for age and 0.81 for gender).

The relationship between age and gender of asthmatic children and their asthma control has been verified in many other studies.

Many previous studies had shown association of male gender with poor asthma control especially before puberty as shown by Borrel et al., however, in the contrary to that result; our study didn't reveal such effect of the gender of studied group on their asthma control level ${ }^{[11]}$

Mahut et al., revealed that for each year with advancement of age from infancy to adolescence, the risk of a severe asthma exacerbation was decreased by $15 \%$ and similarly increases the achievement of asthma control; however, this wasn't the case in our study where no relationship between age of patients and asthma control was verified ${ }^{[12]}$

This can be partly explained by ethnic differences between our study and other studied populations.

Asthma, a phenotypically varied inflammatory disease, is characterized by chronic eosinophilic inflammation and often characterized by enhanced total serum IgE level upon the exposure to allergens, which is known as an atopy ${ }^{[13]}$

The elevated IgE production in asthmatic patients results in promotion of acute hypersensitivity responses, chronic eosinophil-predominant allergic inflammation with Th2 cells cytokine production. Among Th2 cytokines which are responsible for the allergic response and IgE production, IL-4 and TGF- $\beta 1$ seem to be much essential ${ }^{[14]}$

Atopic asthma is affected by both genetic and environmental factors, and the level of atopy, in particular, is an inherited tendency, characterized by high non-specific $\mathrm{IgE}$ and/or high specific IgE against common antigens ${ }^{[15]}$

Plasma cells in the mucosal-associated lymphoid tissue are the major sites of $\operatorname{IgE}$ antibodies production. Synthesis of allergenspecific $\operatorname{IgE}$ in atopic patients is stimulated both by a genetic predisposition to the synthesis of this isotype as well as by environmental factors e.g repeated allergen exposure $^{[16]}$
The production of $\mathrm{IgE}$ from $\mathrm{B}$ cells includes irreversible genetic changes at the Ig heavy chain gene locus which is controlled so tightly. It needs both cytokine signals (TGF$\beta 1$ and IL-4) and interaction of TNF receptor family members on the $B$ cell surface with their ligands ${ }^{[16]}$

In concordance with these data, our study revealed a highly significant elevation of serum levels of total IgE, IL-4, and TGF$\beta 1$ in asthmatics in comparison to nonasthmatic children. Moreover; we found statistically significant positive correlations between the serum levels IL 4, TGF- $\beta 1$ and the total level of serum $\operatorname{IgE}$ in asthmatic children which supports the role of these cytokines in asthma pathogenesis.

Our study revealed also that; the higher serum levels of IgE, IL-4 and TGF- $\beta$ 1 in asthmatic children were associated with poor asthma control.

These results are similar to those found by Antczak et al., where higher serum levels of IL 4 and total IgE were observed in asthmatic group in comparison to nonasthmatics, however, on the contrary to our results, the data in the same study revealed no correlation with asthma control level ${ }^{[17]}$

This difference can be attributed to small sample size in that study (total of 50 patients and 20 controls) relative to our total sample size of 312 patients. Moreover, the mean ages of studied group were older than that observed in our study.

Another study by Panek et al., and in concordance with our results, had found a higher level of circulating TGF- $\beta 1$ in asthmatics in comparison to non-asthmatics [18] Nevertheless, many other studies didn't confirm that relationship. Manuyakorn et al. revealed that Serum TGF- $\beta 1$ in allergic asthma was not different from non-atopic healthy control ${ }^{[19]}$

\section{CONCLUSION}

Our data suggest evidence that serum levels of both TGF- $\beta 1$ and IL-4 are increased in asthmatic children in comparison to nonasthmatics; moreover, they are related to asthma control as their high serum values are associated with poor asthma control. 


\section{STUDY LIMITATION:}

Our study was a single-center study (Zagazig University) with a relatively small sample size due to high cost concerning measurement of TGF- $\beta 1$ and IL-4, and so additional large-scale case-control studies are required to confirm our findings.

\section{REFERENCES}

1- Murphy DM and O'Byrne PM, Recent advances in the pathophysiology of asthma. Chest, 2010; 137:1417-26

2- Daneshmandi S, Pourfathollah AA, Pourpak Z, Heidarnazhad $H$ and Kalvanagh PA Cytokine gene polymorphism and asthma susceptibility, progress, and control level. Mol Biol Rep, 2012; 39:1845-53.

3- Mahdaviani SA, Rezaei N, Moradi B, Dorkhosh S, Amirzargar AL and Movahedi M Proinflammatory cytokine gene polymorphisms among Iranian patients with asthma. J Clin Immunol, 2009; 29(1):5762

4- Halwani R, Al-Muhsen S, Al-Jahdali H and Hamid $\mathbf{Q}$. Role of transforming growth factor- $\beta$ in airway remodeling in asthma. Am J Respir Cell Mol Biol, 2011; 44(2):127-33

5- Zhang W, Zhang X, Qiu D et al., IL-4 receptor genetic polymorphisms and asthma in Asian populations. Respir Med, 2007; 101:186-90

6- Zhang Y, Zhang J, Huang X, Sandford A and Tan WC. Polymorphisms in the transforming growth factor- $\beta 1$ gene and the risk of asthma: A meta-analysis. Respirology, 2010; 15(4): 643-650.

7- National Asthma Education and Prevention Program (NAEEP), National Heart, Lung and Blood Institute, Expert Panel Report 3: Guidelines for the Diagnosis \& Management of Asthma.Summary report. J Allergy Clin Immunol, 2007; 120(5 Suppl):S94-138.

8- Global Initiative for asthma, Global strategy for asthma management and prevention, 2008; available at www.Ginasthma.org. [accessed 09/11/2013]

9- Bandaru S, Marri K, Akka J, Alvala M and Mundluru MP. Association of Transforming Growth Factor-Beta 1 Promoter Variant -509 $\mathrm{C} / \mathrm{T}$ with Bronchial Asthma in South Indian Population Inflammation, 2015; 38(1): 409414

10- Panek M, Pietras T, Fabijan A, Milanowski M, Wieteska L, Gorski P et al., Effect of glucocorticoid receptor gene polymorphisms on asthma phenotypes. Exp Ther Med, 2013; 5: $572-580$.

11- Borrell LN, Nguyen EA, Roth LA, Oh SS, Tcheurekdjian H, Sen S et al., Childhood obesity and asthma control in the GALA II and SAGE II studies. Am J Respir Crit Care Med, 2013; 187:697-702.

12- Mahut B; Trinquart $\mathbf{L}$ and Delclaux $C$, Influence of age on the Risk of Severe Exacerbation and asthma control in Childhood. JOURNAL OF ASTHMA, 2011; 48(1):65-68.

13- Custovic A, Johnston SL, Pavord I, Gaga M, Fabbri L, Bel EH et al., EAACI position statement on asthma exacerbations and severe asthma. Allergy, 2013; 68:1520-31.

14- Hoffjan $\mathbf{S}$ and Ober $\mathbf{C}$, Present status on the genetic studies of asthma. Current Opinion in Immunology, 2002; 14: 709-717.

15- Afshari JT, Hosseini RF, Farahabadi SH, Heydarian F, Boskabady MH, Khoshnavazet $\mathbf{R}$ et al., Association of the expression of IL-4 and IL-13 genes, IL-4 and IgE serum levels with allergic asthma. Iranian Journal of Allergy Asthma Immunology, 2007; 6: 67-72.

16- Hans CO, Regulation and Biology of Immunoglobulin E in Donald Y, Stanley J, Francisco A et al. (eds.): pediatric allergy, principles and practice, $3^{\text {rd }}$ ed.2016, Chapter 4 , pp. 31-39. Elsevier.

17- Antczak A, Domańska-Senderowska D, Górski P, Pastuszak-Lewandoska D, Nielepkowicz-Goździńska A, Szewczyk K et al., Analysis of changes in expression of IL4/IL-13/STAT6 pathway and correlation with the selected clinical parameters in patients with atopic asthma. Int J Immunopathol Pharmacol, 2016; 29(2):195-204.

18- Panek M, Pietras T, Fabian A, Ziolo J, Wieteska L, BEATA Malachowoska B et al., Identification and association of the single nucleotide polymorphisms, C-509T, C+466T and $\mathrm{T}+869 \mathrm{C}$, of the TGF- $\beta 1$ gene in patients with asthma and their influence on the mRNA expression level of TGF- $\beta 1$,Int J Biochem Mol Biol, 2014; 34: 975-986.

19- Manuyakorn W, Benjaponpitak S, Kamchaisatian W, Setthaudom C, Atamasirikul K, Sasisakulporn C et al., Serum TGF- $\beta 1$ in Allergic Asthma Journal of Allergy and Clinical Immunology, 2007; 119: 1, Supplement, Page S85 